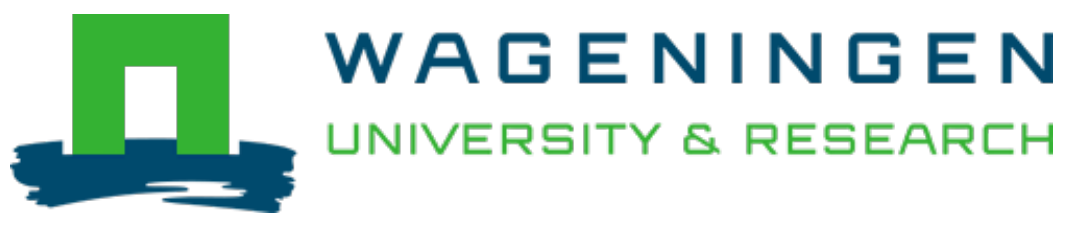

\title{
The effects of processing on the availability of lysine in kenkey, a Ghanaian fermented maize food
}

\author{
International Journal of Food Sciences and Nutrition \\ Nche, P.F.; Nout, M.J.R.; Rombouts, F.M. \\ https://doi.org/10.3109/09637489509012555
}

This publication is made publicly available in the institutional repository of Wageningen University and Research, under the terms of article $25 \mathrm{fa}$ of the Dutch Copyright Act, also known as the Amendment Taverne. This has been done with explicit consent by the author.

Article 25 fa states that the author of a short scientific work funded either wholly or partially by Dutch public funds is entitled to make that work publicly available for no consideration following a reasonable period of time after the work was first published, provided that clear reference is made to the source of the first publication of the work.

This publication is distributed under The Association of Universities in the Netherlands (VSNU) 'Article $25 \mathrm{fa}$ implementation' project. In this project research outputs of researchers employed by Dutch Universities that comply with the legal requirements of Article $25 \mathrm{fa}$ of the Dutch Copyright Act are distributed online and free of cost or other barriers in institutional repositories. Research outputs are distributed six months after their first online publication in the original published version and with proper attribution to the source of the original publication.

You are permitted to download and use the publication for personal purposes. All rights remain with the author(s) and / or copyright owner(s) of this work. Any use of the publication or parts of it other than authorised under article $25 \mathrm{fa}$ of the Dutch Copyright act is prohibited. Wageningen University \& Research and the author(s) of this publication shall not be held responsible or liable for any damages resulting from your (re)use of this publication.

For questions regarding the public availability of this publication please contact openscience.library@wur.nl 


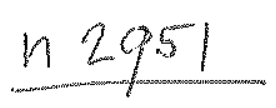

International Joumal of Food Sciences and Nutrition (1995) 46, 241-246

\title{
The effects of processing on the availability of lysine in kenkey, a Ghanaian fermented maize food
}

\author{
P. F. Nche, M. J. R. Nout* and F. M. Rombouts \\ Department of Food Science, Agricultural University, Bomenweg 2, $6703 \mathrm{HD}$ Wageningen, The \\ Netherlands
}

\begin{abstract}
The effects of processing steps such as soaking, fermentation, cooking and drying on the availability of lysine in kenkey were investigated. Soaking increased lysine availability by $21 \%$ and $22 \%$ for maize and maize-cowpea mixtures, respectively. Cooking of soaked samples further improved lysine availability by $68 \%$ and $31 \%$ for maize and maize-cowpea mixtures, respectively. Further significant improvements in lysine availability were effected by fermentation and cooking and values of 3.42 and $4.43 \mathrm{~g} / 16 \mathrm{~g} \mathrm{~N}$ were recorded, respectively for maize and maize-cowpea doughs fermented for 4 days and cooked for $3 \mathrm{~h}$. Cabinet drying had no significant effect on lysine availability, but drum drying of fermented maize and maize-cowpea doughs significantly lowered lysine availability in the resulting kenkey. A 1:1 mixture of cabinet and drum dried flours gave a product with higher available lysine content than the drum dried flour.
\end{abstract}

\section{Introduction}

Lysine is well established as one of the most important amino acids in animal and human nutrition. It has, however, been reported that in certain circumstances not all the lysine present in a protein is nutritionally available to the animal or human consumer (Björck et al., 1983). This is being attributed to the interaction of the $\epsilon$-amino groups of lysine in heatprocessed foods with other food constituents such as sugars, to become nutritionally unavailable (Geervani \& Devi, 1986; Friedman \& Finot, 1990). Many such interactions have been described and they include the reaction of free amino groups with carbonyl groups of sugars and fatty acids to form Maillard browning products, the formation of cross-linked amino acids such as lysinoalanine and glutamyllysine and the steric blocking of the action of digestive enzymes by newly-formed cross-links, as well as native ones such as disulphide bonds (Otterburn, 1989) which can result in the formation of aggregates that are very poorly susceptible to hydrolysis (Deshpande \& Nielsen, 1987). Hence the total lysine content of foods itself is not always an accurate indication of the true nutritional value of the protein with respect to lysine (Hall et al., 1973; Faldet et al., 1992).

Fermented cereal foods such as Ghanaian kenkey are prevalent in developing countries. Although a major energy source, such foods are the only source of a large proportion of the dietary protein which unfortunately is often seriously deficient in lysine (Clark et al., 1977; Friedman \& Finot, 1990). It is, therefore, important that the processing of such foods is carefully controlled in order to maximise lysine availability. This also applies to cereal foods supplemented with legumes in an attempt to

*To whom correspondence should be addressed.

0963-7486/95/030241-06 (c) 1995 Journals Oxford Ltd 
improve both protein quality and quantity. In such cases, it is important that the processing methods used to not undermine the quality improvement process intended with legume supplementation.

Conventional methods used to measure lysine availability in foods are usually either chemical or biological. Biological methods involve the use of microorganisms such as Pediococcus cerevisiae (Hamad \& Fields, 1979a; Umoh \& Fields, 1981). The use of rats and mice in growth response experiments is also on the increase (Sherr et al., 1989; Friedman \& Finot, 1990; Faldet et al., 1992). Several chemical methods have also been used (Conkerton \& Frampton, 1959; Carpenter, 1960; Hall et al., 1973), and most of these have as a basis, the Sanger reaction (Sanger, 1945) involving free $\epsilon$-amino groups of lysine and fluorodinitrobenzene (FDNB) or its derivatives. Hurrell et al. (1979) described a dye-binding method for estimating reactive lysine in foods. Despite some disadvantages, chemical methods involving the use of FDNB and trinitrobenzene sulphonic acid (TNBS) or their derivatives are still being used because they are relatively easy and a large number of samples can be analysed economically (Bakr \& Gawish, 1992; Faldet et al., 1992).

The aim of this work was to compare the effects of various treatments of raw materials during kenkey production on the availability of lysine in the final product. Alternative methods used to prepare kenkey were also evaluated for their effects on lysine availability.

\section{Materials and methods}

Maize (Zea mays L. cv. obantaanba) and cowpea (Vigna unguiculata cv. benpla) were obtained from the Crops Research Institute, CSIR, Kwadaso, Ghana.

\section{Preparation of kenkey}

Traditional and accelerated kenkeys were prepared in the laboratory as described earlier (Nche et al., 1994a,b). In the traditional process (Figure 1), maize or maize-cowpea mixtures $(80: 20)$ were cleaned and soaked for 2 days, after which the soak water was drained and the grains milled and made into a dough that was then placed in sealed plastic containers and allowed to ferment naturally at $30^{\circ} \mathrm{C}$ for 4 days.

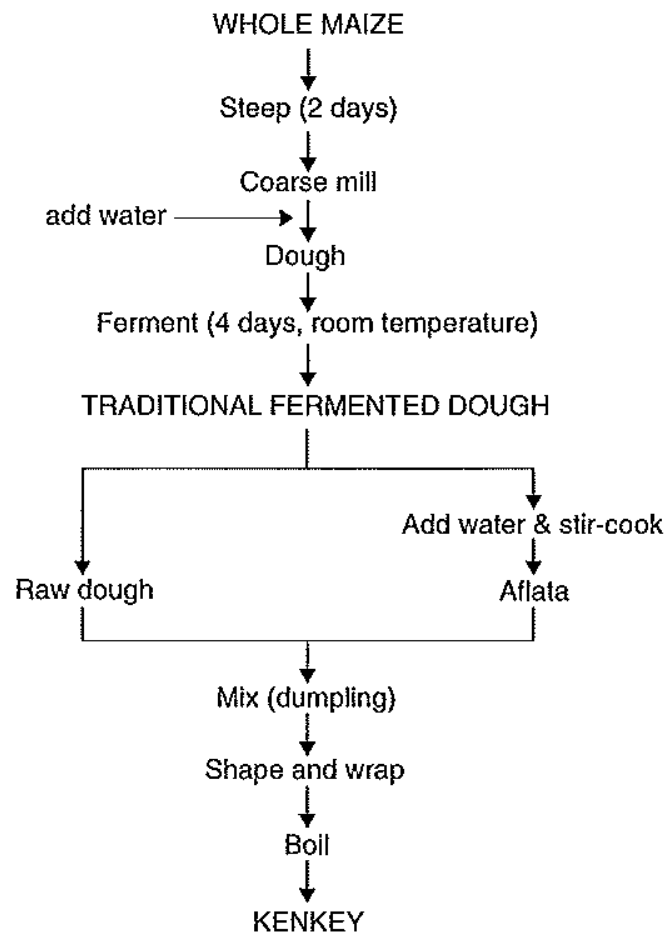

Figure 1. Traditional kenkey process.

Fermented maize or maize-cowpea dough was divided into two parts, one of which was slurried and cooked to gelatinisation to give a gluey paste called the aflata which acts both as a binder and a moisturiser to the uncooked portion. This was then mixed in equal amounts with the uncooked portion, kneaded to give a dumpling from which balls of appropriate size $(\approx 300 \mathrm{~g}$ ) were shaped, wrapped, first in polyethylene sheaths and then in aluminium foil before being cooked in boiling water for $1 \mathrm{~h}$ to give kenkey.

In the accelerated process (Nche et al., 1994b) dry-milled maize was used and dough was fermented for $24 \mathrm{~h}$ at $30^{\circ} \mathrm{C}$. In this case, fermentation was started by a previously fermented dough called 'back-slop' (Nout et al., 1989). After fermentation, the dough was also divided into two portions, one of which was simultaneously pre-gelatinised and dried on a drum-drier (NV Goudse Machinefabriek, Waddinxveen, The Netherlands) to give a dry flour for convenient aflata production. The drum was pre-heated by steam to $140^{\circ} \mathrm{C}$ and set to rotate 
at $1.5 \mathrm{rev} / \mathrm{min}$. The other portion was dried for $5 \mathrm{~h}$ at $45^{\circ} \mathrm{C}$ in a circulating hot air cabinet drier. A 1:1 mixture of the cabinet and drum dried flours was then re-hydrated to give a dumpling from which balls could be shaped and wrapped in aluminium foil before cooking as above to give kenkey. Samples were stored at $-80^{\circ} \mathrm{C}$ until required for analysis.

\section{Sample preparation and sampling}

Wet samples were freeze-dried and all samples were milled to pass through a $0.5 \mathrm{~mm}$ sieve using a hammer mill (Fritsch Pulverisette, Type 14.702, Marius Instruments, Utrecht, The Netherlands). $1 \mathrm{~g}$ of each sample was accurately weighed and placed in a $100 \mathrm{ml}$ volumetric flask containing $8 \mathrm{ml}$ of acetone. $50 \mathrm{ml}$ of $0.1 \%$ agar solution were added and the flask shaken vigorously to ensure adequate mixing. The suspension was then diluted to volume with $0.1 \%$ agar solution. The contents of the flask were transferred into a $250 \mathrm{ml}$ beaker. While still stirring with a magnetic stirrer, $0.5 \mathrm{ml}$ of the suspension was pipetted into calibrated $12 \mathrm{ml} \mathrm{Kimax} \mathrm{tubes} \mathrm{with}$ screw caps. Available lysine was determined as described by Hall et al. (1973).

\section{Determination of lysine availability}

The method described by Hall et al. (1973), an improvement of the Carpenter method was chosen for its simplicity and used to investigate the effect of different processing steps on the availability of lysine in kenkey. In this method fluoro-2,4-dinitrobenzene (FDNB) is replaced by 2,4,6-tri-nitrobenzene sulphonic acid (TNBS, Fluka Chemische Fabrik AG, Buchs SG, Switzerland) during the Sanger reaction with free e-amino groups of lysine.

The total nitrogen was determined by a semiautomatic version of the micro-Kjeldahl procedure (Roozen \& van Boxtel, 1979).

\section{Statistical analyses}

All determinations were in duplicate and repeated 3 times. The data were analysed by an independent $t$-test (SlideWrite Plus, version 5.00, Advanced Graphics Software, Inc., Carlsbad, USA) for significant differences.

\section{Results and discussion}

It is important to stress that although most chemical methods including the one used here are useful for a range of animal materials, they suffer significant drawbacks when applied to plant materials. On the one hand, acid hydrolysis steps employed in some of these methods result in some of the available lysine being rendered unavailable by easily reacting with aldose groups of carbohydrates (Hall et al., 1979), on the other hand, reactions between free amino and carbonyl groups during $\mathrm{HCl}$ hydrolysis can lead to Maillard browning products imparting unwanted coloration which affects spectrophotometric readings in the later stages of the protocols used. The result could be an overestimation of the available lysine content of the food sample (Friedman \& Finot, 1990).

Whilst not ignoring such drawbacks, it must, however, be stressed that this work was aimed more at assessing the comparative effects of processing on the availability of lysine than at absolute quantification of available lysine in kenkey.

The effects of soaking, fermentation time, cooking time, cowpea-supplementation (in traditional kenkey) and cabinet- and drum drying (in accelerated kenkey) on lysine availability were all investigated. Table 1 shows the effects of these treatments on the availability of lysine in raw grains, fermented dough and kenkey from both maize and maize-cowpea blends. Soaking of maize and maize-cowpea blends resulted in significant $(P<0.05)$ increases of $21 \%$ and $22 \%$, respectively, in lysine availability. Cooking of unfermented dough $\left(\mathrm{F}_{0} \mathrm{C}_{1}\right)$ resulted in increases in lysine availability of $68 \%$ and $31 \%$, respectively, for maize and maize-cowpea doughs, compared with soaked samples. Fermentation further increased these values by up to $22 \%$ and $12 \%$ for 2 days' fermented maize and maize-cowpea doughs (i.e. $\mathrm{F}_{2} \mathrm{C}_{1}$ ) respectively, compared with $\mathrm{F}_{0} \mathrm{C}_{1}$. Prolonged fermentation and cooking effected further increases in lysine availability, with the highest values of 3.42 and $4.3 \mathrm{~g} / 16 \mathrm{~g} \mathrm{~N}$ being obtained, respectively, for maize and maizecowpea doughs fermented for 4 days and cooked for $3 \mathrm{~h}$. These values represent improvements of $118 \%$ and $48 \%$, respectively, on the effects of soaking. These results largely agree with those reported by Hamad \& Fields (1979a,b) showing that fermentation of maize and other cereals effected significant improvements in lysine availability. Plahar et al. (1983) reported available lysine values of 2.60 and 
Table 1. Total nitrogen and available lysine contents of maize and maize cowpea blends during processing into kenkey and kenkey dough

\begin{tabular}{|c|c|c|c|c|c|}
\hline \multirow[b]{2}{*}{ Treatment } & & \multicolumn{2}{|c|}{$100 \%$ Maize } & \multicolumn{2}{|c|}{ Maize: cowpea $(80: 20)$} \\
\hline & & $\begin{array}{l}\text { Total nitrogen } \\
(\mathrm{g} / \mathrm{kg} \text { sample })^{1}\end{array}$ & $\begin{array}{l}\text { Available lysine } \\
\text { (g/l6g nitrogen })\end{array}$ & $\begin{array}{l}\text { Total nitrogen } \\
(\mathrm{g} / \mathrm{kg} \text { sample })\end{array}$ & $\begin{array}{l}\text { Available lysine } \\
(\mathrm{g} / 16 \mathrm{~g} \text { nitrogen })\end{array}$ \\
\hline & None & $15.22 \pm 0.34^{2}$ & $1.30 \pm 0.30^{3}$ & $20.49 \pm 0.42$ & $2.46 \pm 0.11^{b}$ \\
\hline & Soaked & $15.48 \pm 0.75$ & $1.57 \pm 0.00^{3}$ & $21.30 \pm 1.46$ & $2.99 \pm 0.19^{\mathrm{c}}$ \\
\hline \multicolumn{6}{|c|}{ Fermented } \\
\hline & $\mathrm{F}_{0} \mathrm{C}_{1}^{3}$ & $16.19 \pm 1.39$ & $2.64 \pm 0.17^{\mathrm{b}}$ & $21.23 \pm 0.81$ & $3.91 \pm 0.00^{\mathrm{e}}$ \\
\hline & $\mathrm{F}_{1} \mathrm{C}_{1}$ & $16.80 \pm 0.90$ & $3.25 \pm 0.26^{\mathrm{d}}$ & $\mathrm{ND}^{4}$ & ND \\
\hline & $\mathrm{F}_{2} \mathrm{C}_{1}$ & $16.46 \pm 0.90$ & $3.21 \pm 0.04^{d}$ & $22.00 \pm 0.50$ & $4.36 \pm 0.07^{i}$ \\
\hline & $\mathrm{F}_{3} \mathrm{C}_{1}$ & $16.96 \pm 0.38$ & $3.29 \pm 0.22^{d}$ & ND & ND \\
\hline \multicolumn{6}{|l|}{ Cooked } \\
\hline & $\mathrm{F}_{4} \mathrm{C}_{0}$ & $18.13 \pm 2.13$ & $2.33 \pm 0.00^{\mathrm{b}}$ & $21.45 \pm 1.66$ & $3.44 \pm 0.40^{d, c}$ \\
\hline & $\mathrm{F}_{4} \mathrm{C}_{\mathrm{I}}$ & $17.99 \pm 1.19$ & $2.36 \pm 0.59^{\mathrm{b}}$ & $21.78 \pm 1.17$ & $4.11 \pm 0.30^{5}$ \\
\hline & $\mathrm{F}_{4} \mathrm{C}_{2}$ & $17.49 \pm 1.38$ & $3.29 \pm 0.04^{\mathrm{d}}$ & ND & ND \\
\hline & $\mathrm{F}_{4} \mathrm{C}_{3}$ & $15.36 \pm 0.21$ & $3.42 \pm 0.17^{\mathrm{d}, \mathrm{e}}$ & $20.63 \pm 0.45$ & $4.43 \pm 0.00^{r}$ \\
\hline
\end{tabular}

${ }^{1}$ Dry weight basis; ${ }^{2} \mathrm{Mean} \pm \mathrm{SD}(n=6) ;{ }^{3} \mathrm{All}$ samples fermented at $30^{\circ} \mathrm{C} ; \mathrm{F}_{0-4}=$ fermented for $0-4$ days; $\mathrm{C}_{0-3}=$ cooked for $0-3 \mathrm{~h} ;{ }^{4} \mathrm{ND}=$ not determined.

a,be,d,e,f Valtues with the same letter are not significantly different $(P<0.05)$.

$3.46 \mathrm{~g} / 16 \mathrm{~g} \mathrm{~N}$ for dehydrated fermented maize meal and maize-soy $(80: 20)$ flour blends, respectively. Zamora \& Fields (1979) also found significant improvements in the availability of limiting amino acids such as isoleucine, methionine and tryptophan following the lactic fermentation of cowpeas. In their studies of the availability of sulphur amino acids in six varieties of common beans (Phaseolus vulgaris), Marletta et al. (1992) reported significant decreases in available cystine in only two varieties, and no changes in the total cystine contents of all six varieties after soaking and cooking. The availability of methionine was, however, reported as unaffected by cooking. This difference in the effects on the availability of cystine and methionine was reported (Marletta et al., 1992) to be due to the presence of different proportions, in various bean proteins (albumins, globulins and glutenins) which have been shown to have different digestibilities (Lanfer Marquez \& Lajolo, 1981).

The total nitrogen contents of all samples remained largely the same regardless of the

Talsle 2. Effects of cabinet and drum drying of maize and maize-cowpea (80:20) doughs on the total uitrogen and available lysine contents of the resulting kenkey

\begin{tabular}{|c|c|c|c|c|}
\hline \multirow[b]{2}{*}{ Process } & \multicolumn{2}{|c|}{$100 \%$ maize } & \multicolumn{2}{|c|}{ Maize: cowpea $(80: 20)$} \\
\hline & $\begin{array}{l}\text { Total nitrogen } \\
(\mathrm{g} / \mathrm{kg} \text { sample })^{\prime}\end{array}$ & $\begin{array}{l}\text { Available lysine } \\
\text { (g/l6g nitiogen) }\end{array}$ & $\begin{array}{l}\text { Total nitrogen } \\
(\mathrm{g} / \mathrm{kg} \text { sample })\end{array}$ & $\begin{array}{l}\text { Available lysine } \\
\text { (g/l6g nitrogen) }\end{array}$ \\
\hline Traditional & $17.99 \pm 1.19^{2}$ & $2.36 \pm 0.59^{\mathrm{c}}$ & $21.78 \pm 1.17$ & $4.11 \pm 0.30^{f}$ \\
\hline $\mathrm{C}$ abinet dried ${ }^{3}$ & $17.72 \pm 0.87$ & $2.69 \pm 0.11^{\mathrm{c}}$ & $20.93 \pm 1.09$ & $4.17 \pm 0.23^{f}$ \\
\hline Drum tried ${ }^{4}$ & $16.89 \pm 1.39$ & $1.59 \pm 0.14^{\mathrm{a}}$ & $21.09 \pm 1.08$ & $3.08 \pm 0.05^{\mathrm{d}}$ \\
\hline Cabinet + drum dried ${ }^{5}$ & $15.48 \pm 0.60$ & $2.07 \pm 0.48^{b}$ & $21.00 \pm 0.77$ & $3.85 \pm 0.05^{\mathrm{e}}$ \\
\hline
\end{tabular}

'Dry weight basis; ${ }^{2}$ mean $\pm \mathrm{SD}(n=6) ;{ }^{3}$ accelerated fermentation plus cabinet drying; ${ }^{4}$ accelerated fermentation plus drum drying; ${ }^{5}$ | $1: 1$ mixture of cabinet- and dnum dried flours.

$a, b, c, d, e, f$ Values with the same letter are not significantly different $(P<0.01)$. 
treatment (Tables 1 and 2). Although not determined, it could be deduced from this that the total lysine contents of all the samples were not significantly altered. Any changes in the amounts of available lysine could, therefore, have been mainly the result of changes in the binding state of total lysine during processing.

A $20 \%$ supplementation with white cowpea resulted in a $74 \%$ increase in the available lysine content of kenkey made by the traditional process $\left(\mathrm{F}_{4} \mathrm{C}_{1}\right)$ in comparison with the all-maize product. This increase is in line with increases in total lysine contents of maize-cowpea blends reported earlier (Nche et al., 1994a).

Accelerated lactic fermentation followed by cabinet drying of dough did not affect lysine availability in the resulting kenkey (Table 2). Drum drying, on the other hand significantly $(P$ $<0.01$ ) reduced the available lysine contents of the resulting kenkeys. Adeniji \& Potter (1978) reported heavy losses of up to $38 \%$ in available lysine of ogi following drum drying. We found a $33 \%$ and $25 \%$ reduction in the amounts of available lysine in drum dried maize and maizecowpea kenkeys, respectively. Addition of an equal amount of cabinet dried flour to drum dried flour to produce kenkey, did not only contribute to the desired texture of the final product, but also compensated for some of the available lysine lost as a result of drum drying (Table 2). The values obtained for available lysine in such mixtures were only $12 \%$ and $6 \%$ lower than for traditional maize and maizecowpea kenkeys, respectively.

Results obtained for lysine availability in the raw materials (Table 1) were generally below the range of values of total lysine contents of raw maize and/or cowpeas although Hamad \& Fields (1979a) reported even lower values for maize. Calculations from literature values (Hurrell \& Carpenter, 1979; Kent, 1983; Bressani, 1985) give average total lysine contents of 2.5 and $3.6 \mathrm{~g} / 16 \mathrm{~g} \mathrm{M}$ for maize and $80: 20$ maize-cowpea blends, respectively. These values are well in line with the crude protein contents of $10.8 \%$ and $13 \%$ reported by Nche et al. (1994a) for maize and a 80:20 maize-cowpea mixture, respectively. The lower values of available lysine for the raw materials, however, could be attributed to the fact that these materials have lower protein digestibilities (Nche et al., 1993) and hence only a fraction of the actual lysine content will be available. Further processing, which includes fermentation and cooking, results in increased protein digestibilities and subsequently increased lysine availability.

The results presented in this paper clearly show that soaking, fermentation and cooking contribute significantly to the protein quality of kenkey. Drum drying will, however, induce high losses in available lysine, but a mixture of cabinet and drum dried flours will, in addition to maintaining the texture of traditional kenkey, limit excessive losses in nutritive value with respect to lysine availability.

Acknowledgements-Financial assistance from the EC (Contract No. TS2-0267-UK; 'The evaluation and improvement of traditional fermented cereals and legumes in Ghana') is gratefully acknowledged. We also thank Dr $\mathrm{H}$. Gruppen for valuable comments.

\section{References}

Adeniji AO \& Potter NN (1978): Properties of ogi powders made from nomal, fortified and opaque- 2 corn. J. Food Sci. 43, 1571-1574.

Bakr AA \& Gawish RA (1992): Nutritional and cooking quality evaluation of dry cowpea (Vigna sinensis L.) grown under different agriculural conditions. $J$. Food Sci. Technol. 29, 375-380.

Bjorck I, Noguchi $\Lambda$, Asp NG, Cheftel J \& Dahlquist A (1983): Protein nutritional value of a biscuit processed from extrusion cooking: effects on available lysine. $J$. Agric. Food Chem. 31, 488-492.

Bressani R (1985): Nutritive value of cowpea. In Cowpea, Research, Production and Utilization, eds DR Singh \& Ko Rachie, pp 353-373. Chichester: John Wiley and Sons.

Carpenter KJ (1960): The estimation of the available lysine in animal-protein foots. The Biochemical Journal 77, $604-610$.

Clark HE, Bailey LB \& Brewer MF (1977): Lysine and tryptophan in cereal-based diets for adult human subjects. Am. J. Clin. Nutr: 30, 674-680.

Conkerton EJ \& Frampton VL (1959): Reaction of Gossypol with free $\epsilon$-amino groups of lysine in proteins. Archiv. Biochem. Biophys. 81, 130-134.

Deshpande SS \& Nielsen SS (1987): $I n$ vitro digestibility of dry bean (Phaseolus vulgaris) proteins: the role of heatstable protease inhibitors. J. Food Sci. 52, 1330-1334.

Faldet MA, Satter LD \& Broderick GA (1992): Determination of optimal heat treatment of soybeans by measuring available lysine chemically and biologically with rats to 
maximize protein utilization by ruminants. $J$. Nutr: $\mathbf{1 2 2}$, 151-160.

Friedman M \& Finot PA (1990): Nutritional improvement of bread with lysine and Y-ghtamyllysine. J. Agric. Food Chem. 38, 2011-2020.

Geervani P \& Devi PY (1986): Effect of different heat treatnents on the losses of lysine in processed products prepared from unfortified flour and flour fortified with lysine. Nutr: Rep. Int. 33, 961-966.

Hall RJ, Trinder N \& Givens DI (1973): Observations on the use of 2,4,6-Trinitrobenzenesulphonic acid for the determination of available lysine in animal protein concentrates. Analyst 98, 673-686.

Hamad AM \& Fields ML (1979a): Evaluation of the protein quality and available lysine of germinated and fermented cereals. J. Food Sci. 44, 456-459.

Hamad AM \& Fields ML (1979b): Nutritional and sensory evaluation of bread made from fermented wheat meal and corn chips made from fermented com meal. J. Food Sci. $44,1514-1516$.

Hurrell RF, Lerman P \& Carpenter KJ (1979): Reactive lysine in foods as measured by a rapid dye-binding procedure. J. Food Sci. 44, 1221-1227, 1231 .

Kent NL (1983): Technology of Cereals, p. 37. New York: Pagamon Press.

Lanfer Marquez UML \& Lajolo FM (1981): Composition and digestibility of albumins, globulins and glutenins from Phaseolus vulgaris. J. Agric. Food Chem. 29, 1068-1074.

Marletta L, Carbonaro M \& Carnovale E (1992): In vitro protein and sulphur amino acid availability as a measure of bean protein quality. J. Sci. Food Agric. 59, 497-504.

Nche PF, Nout MJR \& Rombouts FM (1993): Effects of processing on the dietary fibre content and in vitro digestibility of kenkey, a Ghanaian fermented maize product. In Nutritional, Chemical and Food Processing Implications of Nutrient Availability: Proceedings of
"Bioavailability '93", Part 1, ed. U Schlemmer, p. 196. Ettlingen, Germany.

Nche PF, Nout MJR \& Rombouts FM (1994a): The effect of cowpea supplementation on the quality of kenkey, a traditional Ghanaian fermented maize. Food J. Cereal Sci. 19, 191-197.

Nche PF, Odamtten GT, Nout MJR \& Rombouts FM (1994b): Dry-milling and accelerated fermentation of maize for the industrial production of kenkey, a Ghanaian cereal food. J. Cereal Sci. 21 (in press).

Nout MJR, Beernink G \& Bonants-van Laarhoven TMG (1987): Growth of Bacillus cereus in soya bean tempeh. Iht. J. Food Microbiol. 4, 293-301.

Nout MJR, Rombouts FM \& Havelaar A (1989): Effect of accelerated natural lactic fermentation of infant food ingredients on some pathogenic microorganisms. $l \mathrm{nt} . \mathrm{J}$. Food Microbiol. 8, 351-361.

Otterbum MS (1989): Protein cross-linking. In: Protein Quality and the Effects of Processing, eds RD Phillips \& FIV Finley, pp. 247-261. New York: Dekker.

Plahar WA, Leung HK \& Coon CN (1983): Effects of dehydration and soy fortification on physicochemical, nutritional and sensory properties of Ghanaian fermented maize meal. J. Food Sci. 48, 1255-1259.

Roozen JP \& Van Boxtel L (1979): Galf-attomatische bepaling van stikstof in levensmiddelen. De Waren Chemicus 9, 192-195.

Sanger $F$ (1945): The free amino acids of insulin. Biochemical Journal 39, 507-515.

Sherr B, Lee M \& Jelesciewicz C (1989): Absorption and metabolism of lysine Maillard products in relation to the utilization of L-lysine. J. Agric. Food Chem. 37, $119-122$

Umoh V \& Fields ML (1981): Fermentation of corn for Nigerian ogi. J. Food Sci. 46, 903-905.

Zamora $\mathrm{AF}^{*}$ \& Fields $\mathrm{ML}$ (1979): Nutritive quality of fermented cowpeas (Vigna sinensis) and chickpeas (Cicer arietintm). J. Food Sci. 44, 234-236. 